\title{
Antibacterial and cytotoxic activities screening of symbiotic fungi extract isolated from marine sponge Neopetrosia chaliniformis AR-01
}

\author{
Dian Handayani*, Muh. Ade Artasasta \\ Laboratory of Sumatran Biota, Faculty of Pharmacy, University of Andalas, Kampus Limau Manis 25163, Padang, Indonesia.
}

\begin{tabular}{|c|c|}
\hline ARTICLE INFO & ABSTRACT \\
\hline $\begin{array}{l}\text { Article history: } \\
\text { Received on: } 08 / 11 / 2016 \\
\text { Accepted on: } 07 / 01 / 2017 \\
\text { Available online: } 30 / 05 / 2017\end{array}$ & $\begin{array}{l}\text { Research on the potential of ethyl acetate extracts from symbiotic fungi of marine sponge Neopetrosia } \\
\text { chaliniformis AR- } 01 \text { as producer of cytotoxic and antibacterial compounds has been conducted. Symbiotic fungi } \\
\text { of } N \text {. chaliniformis were isolated by casting method using Sabouraud Dextrose Agar (SDA) and purified by the } \\
\text { scratch method. Pure isolated fungi then was cultivated using rice as media at temperature of } 25-27^{\circ} \mathrm{C} \text { for } 4-8\end{array}$ \\
\hline $\begin{array}{l}\text { Key words: } \\
\text { Marine sponge, symbiotic } \\
\text { fungi, Neopetrosia } \\
\text { chaliniformis, cytotoxic } \\
\text { activity, antibacterial activity. }\end{array}$ & $\begin{array}{l}\text { Shrimp Lethality Test (BSLT) and tested as an antibacterial against pathogenic bacteria of Gram positive } \\
\text { (Bacillus subtilis and Staphylococcus epidermidis) and Gram negative (Escherichia coli and Salmonella } \\
\text { typhosa) using agar diffusion method. There are } 13 \text { symbiotic fungi of marine sponge } N \text {. chaliniformis that had } \\
\text { been isolated. The screening result of the cytotoxic activity showed that } 76.92 \% \text { or } 10 \text { fungi isolates were } \\
\text { classified as cytotoxic with } \mathrm{LC}_{50}<100 \mathrm{ppm} \text {, namely } \mathrm{NC} 01, \mathrm{NC} 02, \mathrm{NC} 03, \mathrm{NC} 05, \mathrm{NC} 06, \mathrm{NC} 07, \mathrm{NC} 08, \mathrm{NC} 09 \text {, } \\
\mathrm{NC} 10 \text {, and NC11. The results of the antibacterial activity screening showed that } 5 \text { isolates namely NC01, NC03, } \\
\text { NC04 NC07 and NC10 could inhibit the growth of pathogenic bacteria by diameter of inhibition zone }>10 \mathrm{~mm} \text {. } \\
\text { Based on the screening results, it can be concluded that ethyl acetate extracts of the symbiotic fungi of marine } \\
\text { sponge } N \text {. chaliniformis are a potential source for producing anticancer and antibacterial compounds. }\end{array}$ \\
\hline
\end{tabular}

\section{INTRODUCTION}

Symbiotic microbes of marine sponge are microbes living in the sponge tissue with mutualism association possibility. There are two ways how the microbe could transmit into the sponge tissue, namely transmitted horizontally as well as vertically. Horizontally, microbes which are located around the environment of sponge transmitted to the sponge tissue due to filter feeder process, while vertically, microbes transmitted to the sponge when the sponge was still in the larval stages (Bright and Bulgheresi, 2010; Hentschel et al., 2012). Basically more than $40 \%$ by volume of the sponge body contains microorganisms which have a biological effect on the sponge itself. For example, through the process of photosynthesis, symbiotic cyanobacteria provide $50 \%$ carbon for energy requirement of specific tropical sponge (Webster and Taylor,

Corresponding Author

Dian Handayani, Laboratory of Sumatran Biota, Faculty of Pharmacy, University of Andalas, Kampus Limau Manis 25163, Padang, Indonesia. Email: dianh_17@yahoo.com
2012; Wilkinson, 1983). In addition, symbiotic microbes of marine sponge could maintain the availability of nutrients for the sponge, stabilize skeleton of sponge, and also produce secondary metabolites against pathogenic microbes (Hentschel et al., 2002). Therefore, Proksch et al., (2002) hypothesized that the symbiotic microbes of marine sponge are original producer of secondary metabolites. Exploration of symbiotic microbes of marine sponge for isolated their secondary metabolites being concern at this time, because they are producer of potential secondary metabolites against various diseases, especially cancer and pathogenic microbial attack (Vasanthabharathi and Jayalakshmi, 2011; Zhou et al., 2014).

In addition, the exploration of symbiotic microbes of marine sponge could suppress exploitation sponge on a large scale and maintaining the ecosystem of the sponge itself. The use of symbiotic microbes of marine sponge is also better because it could be cultured and purified in the laboratory and could be reproduced in a short time and easily manipulated using molecular technology. 
Among the types of symbiotic microorganisms, symbiotic fungi of sponge is known as a manufacturer of the most interesting bioactive compounds (Bhadury et al., 2006) and Ebel, (2011) explained that the fungi isolated from the marine sponge is one of three main sources to produce new secondary metabolites as anticancer and antimicrobial. Methyl-averantin, isolated compound of Aspergillus versicolor was active against tumor cell line (XF498) with $\mathrm{LC}_{50}$ of $0.41 \mu \mathrm{g} / \mathrm{mL}$. Meroterpenoid class of Alternaria sp. obtained from Callyspongia $s p$. was tested as an inhibitor of NF- $k$ B in RAW264.7 cancer cells with $\mathrm{LC}_{50}$ of $39 \mu \mathrm{M}$, and dankastin $\mathrm{C}$ was tested on lymphocytic leukemia cell (P388) with $\mathrm{LC}_{50}$ of $57 \mu \mathrm{g} / \mathrm{mL}$, isolated of Gymnascella dankaliensis obtained from Homaxinella sp. (Lee et al., 2010; Zhang et al., 2013; Amagata et al., 2013). Recently, a preliminary studies on the antimicrobial activity of fungi and bacteria associated with a sponge Haliclona fascigera and Petrosia nigrans of Mandeh Island, West Sumatra have been done (Handayani et al., 2015a, 2015b, 2016a, 2016b). In addition, averantin of Aspergillus versicolor obtained from Neopetrosia $s p$. had activity as antibacterial against several strains of pathogenic bacteria Staphylococcus with its MIC range of $0.78-1.56 \mu \mathrm{g} / \mathrm{mL}$ (Lee et al., 2010). The marine sponge Neopetrosia chaliniformis is one of endemic sponge in Indonesian marine. But until now there is no literature that describes the secondary metabolites of $N$. chaliniformis including secondary metabolites of symbiotic microbes. However, the Neopterosia genus had been a major concern as a producer of secondary metabolites, and also more than 85 secondary metabolites had been isolated from this sponge (Qaralleh et al., 2016).

\section{MATERIAL AND METHODS}

\section{Sponge Material}

$N$. chaliniformis was collected from the island Mandeh, South Coast, West Sumatra, Indonesia, which was taken at a depth of $\pm 10 \mathrm{~m}$ using scuba diving. Sponge was immediately placed in a sterile plastic bag and stored in an ice box. The sponge was identified by Dr. Nicole J. De Voogd, Natural Biodiversity Center, Netherlands. A voucher specimen (AR-01) has been preserved at the Marine Reference Collection, Laboratory of Sumatran Biota, Andalas University, West Sumatra, Indonesia.

\section{Isolation of Symbiotic Fungi from Marine Sponge}

The isolation of fungi was started with sterilization on the surface of the sample. Sponge was rinsed with sterile seawater, and then cut into small pieces. Sponge was taken as much as 10 grams an inserted into Erlenmeyer and add $100 \mathrm{~mL}$ of sterile seawater. Then it was diluted until its concentration $10^{-6}$ and inoculated on SDA (Sabouraud Dextrose Agar) as medium, and incubated at a temperature of $27-29{ }^{\circ} \mathrm{C}$ for 5-7 days. Colonies that have different shapes and colors with other colonies could be regarded as different isolates. Then be purified by the scratch method to obtain pure isolates and identified based on Brigitte (1980).

\section{Cultivation of Isolated Fungi in Medium of Rice}

The pure isolates of symbiotic fungi were cultured in rice as medium and incubated at room temperature for 4-6 weeks until the volume of rice in the Erlenmeyer is overgrown by the fungi (Kjer et al., 2010).

\section{Extraction of Secondary Metabolites from Fungi Isolates}

After fungi isolates grow optimally, each fungus was extracted after optimal growth with maceration with ethyl acetate (EtOAc) in the ratio 1: 1 with 3 repetitions. The extract of ethyl acetate was collected and evaporated in vacuo using a rotary evaporator. The EtOAc extracts were tested for antibacterial activity and cytotoxic.

\section{Screening of Cytotoxic Activity}

Brine shrimp (Artemia salina) eggs were hatched in 500 $\mathrm{mL}$ of filtered seawater under constant aeration for $48 \mathrm{~h}$ at $(27 \pm 2)$ ${ }^{\circ} \mathrm{C}$. After hatching, active nauplii free from egg shells were collected and used for the assay. Five hundred, fifteen and five microliters of all fungi isolate were added in well plate at 1000 ppm, $100 \mathrm{ppm}$ and $10 \mathrm{ppm}$ concentration in triplicate. Fiftteen microliters were added $50 \mu \mathrm{l}$ of DMSO and until $5000 \mu \mathrm{l}$ of seawater containing ten nauplii, while placed in the respective well and maintained at room temperature for $24 \mathrm{~h}$. Filtered seawater was used as negative control. The $\mathrm{LC}_{50}$ value was calculated using curva method based on probit analysis (Meyer et al., 1982).

\section{Screening of antibacterial activity}

For screening of antibacterial activity, the EtOAc extract of symbiotic fungi was tested against Basillus subtilis, Staphylococcus epidemidis, Salmonella typosa and Escherichia coli using the paper disk method. One pieces of $6 \mathrm{~mm}$ sterile paper disk was soaked in each of EtOAc extract (50 mg/ml in DMSO). Paper disks were also inoculated with DMSO (negative control) and Amikacin as positive control. Antagonist activity was detected after incubation for $24 \mathrm{~h}$ at $30{ }^{\circ} \mathrm{C}$. The existence of the clear zone in the media was considered as indicator for antibacterial activity. The zone of inhibition was measured and expressed in millimeters. Strain that showed maximum inhibition was selected to phytochemical test.

\section{Phytochemical Test}

Phytochemical examinations were carried out for all the ethyl acetat extracts of symbiotic fungi as per the standard methods (Tiwari et al., 2011). Phenolic, alkaloid, steroid and terpenoid test were performed to know secondary metabolite constituent by this method.

\section{RESULTS AND DISCUSSION}

Identification of sponge was confirmed as $N$. chaliniformis based on spicules morphology. In Taxonomy, this sponge including Demospongiae class, and part of the family petroicidae.In this study, 13 symbiotic fungi were isolated from 
the sponge. Based on the results of the cytotoxic test screening, 10 fungi isolates or approximately $76.92 \%$ of the total fungi isolates were potentially to produce cytotoxic compounds with their cytotoxic activity below $100 \mathrm{ppm}$. The cytotoxic isolates were NC01, NC02, NC03, NC05, NC06, NC07, NC08, NC09, NC10 and $\mathrm{NC} 11$. The most cytotoxic activity of total isolates was $\mathrm{NC} 01$ with $\mathrm{LC}_{50}$ of $16.79 \mathrm{ppm}$.

Table 1: $\mathrm{LC}_{50}$ value of symbiotic fungi extracts

\begin{tabular}{ccc}
\hline No & Fungi extract & LC $_{\mathbf{5 0}}(\mathbf{p p m})$ \\
\hline 1 & NC01 & 16.79 \\
2 & NC02 & 26.04 \\
3 & NC03 & 39.81 \\
4 & NC04 & 371.53 \\
5 & NC05 & 25.58 \\
6 & NC06 & 54.95 \\
7 & NC07 & 60.12 \\
8 & NC08 & 71.38 \\
9 & NC09 & 26.99 \\
10 & NC10 & 94.62 \\
11 & NC11 & 79.48 \\
12 & NC12 & $>1000$ \\
13 & NC13 & 969 \\
\hline
\end{tabular}

Antibacterial activity test results are listed in Table 2. In this study, 5 fungi extracts (NC01, NC03, NC04, $\mathrm{NC07}$ and $\mathrm{NC10}$ ) showed inhibitory activity against pathogenic bacteria test with diameter of inhibition zone more than $10 \mathrm{~mm}$. The highest antibacterial activity result was shown by extract of $\mathrm{NC} 07$ against bacterial pathogens of B. subtilis, S. epidermidis, S. typhosa and E.coli ( each inhibition zone of $20.9 \mathrm{~mm}, 23.25 \mathrm{~mm}, 22.85$, and $20.9 \mathrm{~mm})$.

Table 2: Antibacterial activity of symbiotic fungi extracts against human pathogenic bacteria.

\begin{tabular}{ccccc}
\hline \multirow{2}{*}{ Fungi } & \multicolumn{4}{c}{ Zone of Inhibition (mm) } \\
\cline { 2 - 5 } Extract & \multicolumn{2}{c}{ Gram positive } & \multicolumn{2}{c}{ Gram negative } \\
\cline { 2 - 5 } & B. subtilis & S. epidermidis & S. typhosa & E. coli \\
\hline NC01 & 8.95 & 7.85 & 10.25 & 7.2 \\
NC02 & - & - & - & - \\
NC03 & 8.75 & 12.6 & 15.25 & 12.85 \\
NC04 & 10.65 & 10.5 & 10.65 & 8.3 \\
NC05 & - & - & - & - \\
NC06 & - & - & - & - \\
NC07 & 20.9 & 23.25 & 22.85 & 20.9 \\
NC08 & 7.2 & 8.95 & 8.3 & 7.45 \\
NC09 & 8.95 & 7.85 & 8.9 & 8.3 \\
NC10 & 8.85 & 11.75 & 10.25 & 9.4 \\
NC11 & 7.85 & 7.45 & 7.45 & 8.3 \\
NC12 & - & - & - & - \\
NC13 & - & - & - & - \\
Amikacin & 23 & 22.7 & 20 & 20 \\
\hline
\end{tabular}

Analysis of the chemical reaction of ethyl acetate extract of symbiotic fungi isolates from $N$. chaliniformis was conducted to determine the constituents of secondary metabolites. In this study, phenolic, alkaloid, steroid and terpenoid were tested using appropriate reagents. Based on the results of phytochemical examinations, most of fungi extracts contain terpenoids, but does not contain alkaloids. In addition, some of fungi extracts contain phenolics and terpenoids (isolates
$\mathrm{NC} 02, \mathrm{NC} 08, \mathrm{NC} 10$ and $\mathrm{NC12}$ ) and other fungi extracts containing steroid (isolates $\mathrm{NC} 01, \mathrm{NC} 05, \mathrm{NC} 09$ and $\mathrm{NC} 13$ ).

Table 3: Phytochemical constituent of ethyl acetate extract of symbiotic fungi.

\begin{tabular}{ccccc}
\hline Fungi & \multicolumn{4}{c}{ Chemical constituent } \\
\cline { 2 - 5 } Extract & Phenolic & Alkaloid & Steroid & Terpenoid \\
\hline NC01 & - & - & + & - \\
NC02 & + & - & - & + \\
NC03 & - & - & - & + \\
NC04 & - & - & - & + \\
NC05 & - & - & + & - \\
NC06 & - & - & - & + \\
NC07 & - & - & - & + \\
NC08 & + & - & - & + \\
NC09 & - & - & + & - \\
NC10 & + & - & - & + \\
NC11 & - & - & - & + \\
NC12 & + & - & - & + \\
NC13 & - & - & + & - \\
\hline “ ”indicates positive reaction; “"” indicates negative reaction.
\end{tabular}

The results of the screening of cytotoxic and antibacterial activity showed that isolates $\mathrm{NC} 01$ most cytotoxic. The results of the macroscopic identification, $\mathrm{NC} 01$ had bluish green with white edges. Diameter colonies after 10 days of growth is $\pm 2.5 \mathrm{~cm}$ at 28 - C. The microscopic identification, NC01 had conidiophore ingreen with a smooth surface and had branched monoverticillate. Hyphae of fungal isolate NC01 was not septape and the phialid was slender clyndrical. From the macroscopic and microscopic observations, NC01 was identified as Penicillium sp.

A symbiotic fungus of $\mathrm{NC} 07$ is the most active as an antibacterial agent. Based on identification macroscopically, fungal colonies are black. Diameter of colony after 10 days was 5 $\mathrm{cm}$ at $28^{\circ} \mathrm{C}$. Microscopically, NC07 showed black conidiophore with a smooth surface, and also had spherical vesicles. Based on the results of macroscopic and microscopic identification, the fungal NC07 classified as Aspergillus niger.

Basically, cytotoxic compounds are toxic compounds which characterized by the death cell after interacting with it. However, to become potential anticancer agents, a cytotoxic compound at least have to show selectivity towards normal and cancer cell, have activity against multidrug-resistent (MDR), and show the cell death mechanism through inhibiting non-apoptotic. In other words, not all cytotoxic compounds could be used as an anticancer agent (Gomes et al., 2015).

Secondary metabolites of symbiotic fungi of marine invertebrates repeatedly show their ability to kill cancer cells through non-apoptotic cell death mechanisms (Gomes et al., 2015). For example, the ethyl acetate extract of Aspergillus versicolor which isolated from Neopetrosia $s p$. had cytotoxic activity with $\mathrm{LC}_{50}$ of $32 \mu \mathrm{g} / \mathrm{mL}$ (Lee et al., 2010). The moreterpenoid, isolated compound from symbiotic fungi of Altenaria sp. had been reported by Zhang et al. (2013). This compound can inhibit the NF-kB in cancer cells of RAW264.7 with LC50 of $39 \mu \mathrm{M}$. NF-kB is a marker of most cancer incidence as well as key transcription factors that are involved in the inflammatory reaction, therefore inhibition of the formation of NF$\mathrm{kB}$ will inhibit the growth of tumor cells (Vallabhapurapu and 
Karin, 2009). Antibacterial compounds from symbiotic fungi of marine sponge are a potential source and being concern lately (Zhou et al. 2014). It has been reported that several strains of symbiotic fungi of marine sponge could produce a potential antibacterial compound. Henriquez et al. (2013) reported that the extract of the symbiotic fungi from Antartic marine sponge could inhibit some pathogenic bacteria such as $P$. aeruginosa, $S$. aureus with the inhibition zone diameter above $10 \mathrm{~mm}$. Moreover, the ethyl acetate extract of the Penicillium sp. which obtained from marine sponge of South China Sea could inhibit both of Gram positive and Gram-negative pathogenic bacteria. Further investigation showed that Penicillium sp. contains penicifuran A which was capable for inhibiting pathogenic bacteria $S$. albus with minimum inhibitory concentration (MIC) of 3,13 $\mu \mathrm{M}$ (Qi et al., 2013).

\section{CONCLUSION}

Symbiotic fungi of marine sponge $N$. chaliniformis AR01 with code NC01 (Penicillium sp.) and NC07 (Aspergillus niger) were the most potential fungi isolates to produce anticancer and antibacterial compounds. The presence of cytotoxic activity and antibacterial activity were suspected due to the presence of secondary metabolites content of steroids and terpenoids.

\section{ACKNOWLEDGEMENT}

We are grateful to Dr. Nikole J. De Voogd, Natural Biodiversity Center, Netherlands for identification of the marine sponge.

Financial support and sponsorship: This research was funded by Ministry of Research and Technology, Indonesia in project "Master Program of Education Leading to Doctoral Degree for Excellen Graduate (PMDSU) research, No: 324/SP2H/LT/DRPM/IX/2016".

Conflict of Interests: There are no conflicts of interest.

\section{REFERENCES}

Amagata T, Tanaka M, Yamada T, Chen YP, Minoura K, and Numata A. Additional cytotoxic substances isolated from the sponge-derived Gymnascella dankaliensis. Tetrahedron Lett, 2013; 54:5960-5962.

Bhadury P, Mohammad BT, and Wright PC. The current status of natural products from marine fungi and their potential as anti-infective agents. J. Ind. Microbiol. Biotechnol, 2006; 33:325-337.

Bright $M$ and Bulgheresi S. A Complex Journey: Transmission of Microbial Symbionts. Nature Reviews (Microbiology), 2010; 8:219-230.

Brigitte G. Kompendium der Medizinschen Mykologi. 1980, BerlinHamburg. Verlag Paul Parey.

Gomes NGM, Lefranc F, Kijjoa A and Kiss R. Can Some MarineDerived Fungal Metabolites Become Actual Anticancer Agents? Marine Drugs, 2015; 13:3950-3991.

Handayani D, Ahdinur RF, Rustini R. Antimicrobial Activity of Endophytic Fungi from Marine Sponge Haliclona fascigera. Journal of App Pharm Sci, 2015a; 5: 154-156.

Handayani D, Sandrawaty N, Murniati M, and Regina,R. Screening of Endophytic Bacteria Isolated from Marine Sponge Haliclona fascigera for Inhibition against Clinical Isolates of Methicillin Resistant Staphylococcus aureus (MRSA). J. App Pharm Sci, 2015b; 5(9): 139-142.
Handayani D, Murniati M and Rustini R. In Vitro Inhibitory Activity of Ethyl Acetat Extract of Symbiotic Bacteria Isolated from Marine Sponge Haliclona fascigera against Multidrug Resistant Organism (MDRO). J App Pharm Sci, 2016a; 6 (11): 218-222.

Handayani D, Ornando R, ,Rustini. Antimicrobial activity screening of symbiotic fungi from marine sponge Petrosia nigrans collected from south coast of West Sumatera, Indonesia. International Journal of Pharmacognosy and Phytochemical Research, 2016b; 8(4): 623-626.

Henriquez M, Vergara K, Norambuena J, Beiza A, Maza F, Ubilla P, Araya I, Chavez R, Martin AS, Darias J, Darias MJ, and Vaca I. Diversity of Cultivable Fungi Associated With Antartic Marine Sponges and Screening for their Antimicrobial, Antitumorial and Antioxidant Potential. World J. Microbiol Biotechnol, 2013; 30: 65-76.

Hentschel U, Hopke J, Horn M, Friederich AB, Wagner M, Hacker $\mathrm{J}$, and Moore BS. Molecular Evidance for a Uniform Microbial Community in Sponges from Diffrent Oceans. Applied and Environmental Microbiology, 2002; 68: 4432-4440.

Hentschel U, Piel J, Degnan SM, and Taylor MW. Genomic Insights Into the Marine Sponge Microbiome. Nature Review Microbiology, 2012; 10(9):61-654.

Kjer J, Debbab A, Aly AH, dan Proksch, P. Methods for isolation of marine-derived endophytic fungi and their bioactive secondary products Nature Protocols, 2010; 5:479-490.

Lee YM, Li H, Hong J, Cho HY, Bae KS, Kim MA, Kim DK, and Jung JH. Bioactive Metabolites from the Sponge-Derived Fungus Aspergillus versicolor. Archives of Pharmacal Research, 2010; 33:231-235.

Meyer BN, Figni NR, Putman JE, Jacobsen DE, Nichols DE, and Mc-Laughlin JL. Brine shrimp: A convient general bioassay for active plant constituents. Planta Medica,1982; 45:31-34.

Proksch P, Edrada RA, and Ebel R. Drugs from the Seas - Current Status and Microbiological Implications. Appl Microbiol Biotechnol, 2002; 59:125-134.

Qaralleh H. Chemical and Bioactive Diversites of Marine Sponge Neopetrosia. A Journal of the Bangladesh Pharmacological Society, 2016; 11:433-452.

Qi J, Shao CL, Li ZY, Gan LS, Fu XM, Bian WT, Zhao HY, and Wang CY. Isocoumarine Derivates and Benzofurans from a Sponge-Derived Pencillium sp. Fungus. Journal of Natural Products, 2013; 76(4):571-9.

Rateb ME, and Ebel R. Secondary Metabolites of Fungi from Marine Habitats. Nat. Prod. Rep, 2011; 28: 290-344.

Tiwari P, Kumar B, Kaur M, Kaur G., and Kaur H. Phytochemical screening and Extraction: A Review, Internationale Pharmaceutica Sciencia, 2011; 1(1): 98-106.

Vallabhapurapu S, Karin M. Regulation and Function of NF-kB Transcription Factor in Immune System. Annu. Rev. Immunol, 2009; 27:693733.

Vasanthabharathi V, and Jayalakshmi S. Bioactive potential of symbiotic bacteria and fungi from marine sponges. African Journal of Biotechnology, 2011; 11:7500-7511.

Webster NS, and Taylor M. Marine Sponges And Their Microbial Symbionts : Love And Other Relationships. Environmental Microbiology, 2012; 14:335-346.

Wilkinson CR. Net primary productivity in coral reef sponges. Science, 1983; 219: 410-412.

Zhang G, Wu G, Zhu T, Kurtain T, Mandi A, Jiao J, Li J, Qi X, Gu $\mathrm{Q}$, and $\mathrm{Li} \mathrm{D}$. Meroterpenoids with diverse ring systems from the spongeassociated fungus Alternaria sp. JJy-32. Journal of Natural Products, 2013; Doi : 10.1021/np4005757.

Zhou Y, Debbab A, Wray V, Lin W, Schulz B, Trepos R, Pile C, Hellio C, Proksch P, and Aly AH. Marine Bacterial Inhibitors from the Sponge-Derived Fungus Aspergillus sp. Tetrahedron Letters, 2014; 56:27892792 .

\section{How to cite this article:}

Handayani D, Artasasta MA. Antibacterial and cytotoxic activities screening of symbiotic fungi extract isolated from marine sponge Neopetrosia chaliniformis AR-01. J App Pharm Sci, 2017; 7 (05): 066-069. 